Cite as: Philip. G. C., \& Moon, S-Y. (2013). An investigation of student expectation, perceived performance and satisfaction of e-textbooks. Journal of Information Technology Education: Innovations in Practice, 12, 287-298. Retrieved from http://www.jite.org/documents/Vol12/JITEv12IIPp287-298Philip353.pdf

\title{
An Investigation of Student Expectation, Perceived Performance and Satisfaction of E-textbooks
}

\author{
George C. Philip and Soo-Young Moon \\ The University of Wisconsin - Oshkosh, \\ Oshkosh, Wisconsin, USA
}

philip@uwosh.edu, moon@uwosh.edu

Executive Summary

This paper examines the use of e-textbooks in a college level introductory information systems course using an empirical study that gave students the option to buy electronic or print versions of the same textbook. The study measured and analyzed student expectations prior to purchase, perceived performance and satisfaction after use, intention to use e-textbooks in the future and the determinants of satisfaction using factor analysis and regression modeling, with a consumer behavior focus.

Student reactions to e-textbook were mixed, indicating that students did not perceive the benefits to outweigh the drawbacks particularly due to lack of naturalness in e-textbooks. The study found that the level of satisfaction of e-textbook users is almost the same as that of print book users. On the average, the probability that e-textbook users will choose e-textbook over print book in the future is less than moderately high. Further, there is only a low probability that print book users will switch to the electronic version. There is, however, a slight improvement of student attitudes over past studies.

Analysis of the determinants of satisfaction indicates that performance is the key determinant of satisfaction, and, unlike the results of certain consumer satisfaction studies, this study shows that expectation prior to using e-textbook has minimal impact on satisfaction.

The study suggests that although e-textbooks have the potential to be an effective low-cost option, further improvement in cost as well as features that make them more natural, appealing and effective is necessary for wider acceptance by students.

Keywords: E-textbook, E-book, E-learning, Consumer Behavior.

Material published as part of this publication, either on-line or in print, is copyrighted by the Informing Science Institute. Permission to make digital or paper copy of part or all of these works for personal or classroom use is granted without fee provided that the copies are not made or distributed for profit or commercial advantage AND that copies 1) bear this notice in full and 2) give the full citation on the first page. It is permissible to abstract these works so long as credit is given. To copy in all other cases or to republish or to post on a server or to redistribute to lists requires specific permission and payment of a fee. Contact Publisher@InformingScience.org to request redistribution permission.

\section{Background}

The Internet and the electronic age are transforming education in unprecedented ways with increasing use of online courses, e-books, and other online resources. The concern over increasing costs of higher education, including the cost of textbooks, is playing a major role in this transformation. The 
Investigation of Student Expectation, Perceived Performance and Satisfaction of E-textbooks

cost of textbooks, which has been rising even faster than healthcare costs, has become a cause of outcry in recent times (Kingkade, 2013). E-textbooks, with their lower costs (Falc, 2013; Young, 2009), ease of search, copy and paste (Li et al., 2011; Lyman, 2008), instant access and potential to improve effectiveness through interactivity and multimedia, appear to be the right tool at the right time.

The broader e-book business has seen an impressive growth rate of over 300\% in the last three years, though the rate of growth was relatively lower in 2012, bringing e-books sales close to $22 \%$ of the total U.S. book sales (Hoffelder, 2013). Amazon, which has close to $45 \%$ of the ebook market, reported a 2012 growth rate of $70 \%$ in e-book sales while describing the growth rate of physical books as flattening out (Owen, 2013).

The textbook industry also is undergoing similar changes. Unlike past college students, who transitioned into the digital devices and are described as "digital immigrants," the current college students, who are "digital natives," grew up in the digital age, and are accustomed to the electronic media. Their familiarity with reading online content and their expectations of interactivity, multimedia presentations and instant access to information are potential catalysts to the transition from print books to e-textbooks. In a recent survey, $70 \%$ of almost 2900 students in an east-coast liberal arts college reported that they have used an e-book (Price, 2013). The library of that college, which provides access to over 400,000 e-books, reported an increase of $300 \%$ in downloads of e-books in a two-year period.

In addition to market pressures, including authors bypassing traditional publishers (BakerEveleth, Miller \& Tucker, 2011) and the College Open Textbooks movement (College Open Textbooks, 2013) that aims to make free e-textbooks for students at community colleges, the textbook industry is motivated also by the potential for reduced costs of production and distribution to students and faculty. Almost every major textbook publisher is offering digital versions of textbooks along with physical books. CourseSmart, which partners with several major textbook publishers, claims to have $90 \%$ of all textbooks available as e-books; offers free apps to read, search, highlight copy and paste text, and take notes for a variety of eReaders and smart phones; and allows up to five e-books to be checked out to read offline (CourseSmart, 2013). Flatworldknowledge, a relatively newer textbook publisher, offers over 100 customizable etextbooks (Flatworldknowledge, 2013). Apple's recent push for e-textbooks, including its iBooks app for iPad that supports interactivity of e-textbooks and the free authoring tool iBooks Author app to create multi-touch interactive digital textbooks for iPad, is particularly noteworthy (Apple, 2013).

Textbook publishers, however, are cautious about not cannibalizing their print book sales (Diaz, 2012). Is caution and reluctance by major publishers robbing students of potential benefits of etextbooks?

Though e-textbooks seem to have momentum, there are significant challenges to overcome. Student attitudes in the past toward e-textbooks and e-books, in general, haven't been very favorable. (Buzzetto-More, Sweat-Guy \& Elobaid, 2007; Li et al., 2011; Woody, Daniel \& Baker, 2010) report that the majority of undergraduate students surveyed indicated a preference for print books over electronic versions. Students' complaints include eye strain (Young, 2009) and difficulty in concentrating ( $\mathrm{Li}$ et al.,2011). From a study involving graduate students, Thayer et al. (2011) report that e-books make it difficult to annotate and to map out ideas. Though not specifically using e-textbooks, a study by Sellen and Harper (2002) comparing the use of digital documents to print documents found that print documents are better for annotating, navigating, cross referencing multiple documents and interweaving reading and writing. Similar results were reported by O'Hara and Sellen (1997) from a study comparing the use of Microsoft Word digital documents with print documents, for interweaving reading and writing. 
In a study that used a prompted think-aloud method, Berg, Hoffmann and Dawson (2010) concluded that the students did not intuitively know how to navigate and use e-books effectively. Shepperd, Grace and Koch (2008) found that students who used an e-textbook that was distributed on CDs and DVDs, were generally neutral in their liking for the e-book but found it to be useful. They rated the convenience and willingness to use in the future, unfavorably. Thomas (2007) reported results of surveys that show reluctance to use electronic media for sustained reading activity. A recent study by Falc (2013) in an introductory speech class showed mixed results; close to one half of the students reported difficulty in accessing the e-textbook or related materials, and an equal number stated that they enjoyed using the e-textbook.

Several studies have looked at the factors that promote students' use of e-textbooks and other online materials. In a recent survey of students in a western university in the U.S., Stone and Baker-Eleveth (2013) found that usefulness, ease of use, and students' arousal (interest and stimulation) regarding e-textbooks significantly increase the likelihood to purchase an e-textbook, while perceived value of e-textbooks and students' willingness to search for low price textbooks did not impact their likelihood to purchase. In a study of student access to online instructional materials, Murray, Pérez, Geist, and Hedrick (2012) found that students' access of course content is impacted by their perception of how it will enhance performance and outcomes on assignments and assessments. Studies done by Galy, Downey and Johnson (2011) suggest that student perceptions of e-learning tools impact their decision to choose between online and in-class sections of a course, and that perceived usefulness and perceived ease of use of e-learning tools significantly impact students' final grades.

In a related study on the use of online materials (Wong, 2013), students rated recorded lectures and tutorials as the most effective in assisting learning, which raises the question, what would be the impact of audio versions of e-textbooks on student attitudes?

Studies on student achievement (Daniel \& Woody, 2013; McFall, 2005; Murray \& Pérez, 2011; Rockinson-Szapkiw, Courduff, Carter \& Bennet, 2013; Shepperd et al., 2008), in general, showed no significant difference between students using e-textbooks and those using print books.

This paper examines the use of e-textbooks in a college level course with a consumer behavior focus. The study measures and analyzes student expectations prior to purchase, perceived performance and satisfaction after use and intention to use e-textbooks in the future. Further, the paper examines how students' expectation and perceived performance impact their satisfaction, and compares satisfaction of students using e-textbook and those using print books. The paper uses an empirical study in which students were given the option to buy electronic or print versions of the same textbook.

The results of this study would be of interest to multiple groups including faculty, publishers, authors and book stores. Insight into student satisfaction with e-textbooks, how they compare with print books and what determines student satisfaction are valuable for academicians in adoption decisions and to understand the challenges, especially as universities consider offering e-textbook as the only option for students (Kolowich, 2010; Murray \& Pérez, 2011). Such insights also help the textbook industry to address student concerns and develop marketing strategies.

\section{Research Questions}

A broad question addressed here is whether the findings of consumer satisfaction studies on the relationship between satisfaction, perceived performance and expectation are applicable to etextbooks. Under expectations disconfirmation theory (Oliver, 1997; Yi, 1990), consumers form expectations of product performance prior to purchase, and they compare these expectations to the perceived performance. This theory postulates that disconfirmation, defined as the difference 
between perceived performance and expectation, is the primary determinant of consumer satisfaction.

Churchill and Surprenant (1982) recognized that consumer involvement (Engel \& Blackwell, 1982) in the decision process could play an important role in consumer satisfaction. Their study used durable goods as a high involvement item and nondurable goods as a low involvement item. Their findings on nondurable goods supported the disconfirmation theory, but the results on durable goods showed that product performance alone affected satisfaction. In a recent study, Moon, Philip and Moon (2011) found that perceived performance was the key determinant of satisfaction for both the high involvement group and the low involvement group in e-shopping.

The specific questions addressed in this paper are:

First, is there a difference in satisfaction between e-textbook users and print book users?

Second, what were students' expectations of the e-textbook prior to usage? What was students' perceived performance after they used the e-textbook? How satisfied were students after usage?

Third, which model, the disconfirmation model or the perceived performance model that postulates that performance is the key determinant of satisfaction, is appropriate to the selection of the e-textbook?

Fourth, is there a difference between e-textbook users and print book users in the probability that they will choose e-textbooks if they have the choice of print or electronic versions?

Fifth, what is the probability that print book users will switch to the electronic version.

\section{Research Methodology}

This study uses 240 usable responses from a survey of 256 undergraduate students in an introductory information systems course that is required for all business majors in a Midwestern U.S. university. Students were given the choice to buy electronic or print versions of the same textbook. The questionnaire was adapted from an instrument developed and tested by the authors for a previous survey. The survey asked students about their expectations prior to use, perceived performance and satisfaction after use and intention to use e-textbooks in the future. The study uses a multi-item scale of three constructs (expectations, perceived performance and disconfirmation) based on the guidelines of Parasuraman, Zeithaml, and Berry (1988). These three constructs and the intention to use were measured with a global seven-point scale.

The study compares the satisfaction of e-textbook users and print book users using descriptive statistics. The perceived performance of e-textbook on ten different features, represented by questionnaire items, is examined using descriptive statistics and compared to student expectations prior to use. Further, simple and multiple regression models are used to examine the relationships between satisfaction and the three constructs: expectations, perceived performance and disconfirmation. Factor analysis on the ten items is used to identify the indices and the items with significant correlation with the indices, as discussed later in the section, Determinants of Satisfaction.

The following hypothesis was formulated to test differences in satisfaction between e-textbook users and print book users:

Hypothesis 1: There is no difference in satisfaction between e-textbook users and print book users.

Three additional hypotheses were developed to identify the relationship between satisfaction and the three constructs: expectations, perceived performance, and disconfirmation (performance minus expectation). 
Hypothesis 2: Satisfaction has a positive relationship with expectations.

Hypothesis 3: Satisfaction has a positive relationship with perceived performance.

Hypothesis 4: Satisfaction has a positive relationship with disconfirmation.

To test whether there is a difference between e-textbook users and print book users in their intention to use e-textbooks in the future, a fifth hypothesis was developed:

Hypothesis 5: There is no difference between e-textbook users and print book users in their intention to use e-textbooks.

\section{Results}

Student responses from the survey were analyzed using the SPSS Statistics software. Of the 240 students, 156 used the electronic version and 84 used the print book. Eighty-six percent of etextbook users accessed it online, 7\% used e-readers and 7\% down loaded the PDF version. This section presents analysis of student expectation, perceived performance, satisfaction, the determinants of satisfaction and intention to use e-textbook in the future

\section{Satisfaction: Electronic vs. Print Versions}

Table 1 presents the average satisfaction, measured on a 7-point scale (1 - very dissatisfied; 7 - very satisfied), for students who chose e-textbooks and for those who chose print books.

\begin{tabular}{|l|r|r|r|r|}
\hline \multicolumn{5}{|c|}{ Table 1: Satisfaction: e-textbook vs. print book } \\
\hline & $\begin{array}{c}\text { Mean } \\
\text { Satisfaction }\end{array}$ & $\begin{array}{c}\text { Sample Size } \\
\text { (n) }\end{array}$ & Variance & \multicolumn{1}{c|}{ t Value } \\
\hline E-textbook & 4.73 & 156 & 1.74 & $\begin{array}{r}0.173 \\
\text { Print book }\end{array}$ \\
\cline { 1 - 4 } & 4.70 & 84 & 1.47 & \\
\hline
\end{tabular}

The average satisfaction of e-textbook users is almost identical to those of print book users. There is no evidence to reject Hypothesis 1 (There is no difference in satisfaction between e-textbook users and print book users). E-textbooks are touted to have the benefit of lower cost, ease of search, copy and paste, instant access and improved effectiveness through interactivity and multimedia features. Then why is the satisfaction for e-textbooks the same as that for print books? We postulate several reasons. Although e-textbooks potentially have the above advantages, these benefits are not fully realized in the e-textbook that was used in the study and in e-textbooks, in general, potentially due to the newness of e-textbooks and the half-hearted entry of the publishers into the field. Additional insight on the reasons for student satisfaction with e-text book can be gained by examining the perceived performance of e-textbooks, which is the predominant factor that determines satisfaction, as shown in the next section.

\section{Expectation, Perceived Performance and Disconfirmation}

Table 2 presents student expectations, their perceived performance of e-textbooks after use and the difference between performance and expectation, in ten different areas, with the four lowest performance scores shown in bold.

Overall, students perceived e-textbook to perform somewhat well, and the performance was consistent with their expectations. The average rating of performance of e-textbooks was 4.97 on a 7-point scale (1 - low; 4 - neither low nor high; 7 - very high). 


\begin{tabular}{|l|r|r|r|}
\hline \multicolumn{5}{|c|}{ Table 2: E-textbook expectation, perceived performance and disconfirmation } \\
\hline & $\begin{array}{c}\text { Expectation } \\
\text { 1-very low } \\
\text { 7-very high }\end{array}$ & $\begin{array}{c}\text { Performance } \\
\text { 1-very inferior } \\
\text { 7- very superior }\end{array}$ & $\begin{array}{c}\text { Disconfirmation } \\
\text { (Performance minus } \\
\text { Expectation) }\end{array}$ \\
\hline $\begin{array}{l}\text { eTextbook is convenient to access } \\
\text { (readily available) }\end{array}$ & 5.50 & 5.60 & 0.10 \\
\hline eTextbook is easy to access & 5.49 & 5.33 & -0.16 \\
\hline eTextbook is easy to read & 4.89 & 5.04 & 0.15 \\
\hline eTextbook is convenient to annotate & 4.66 & $\mathbf{4 . 6 7}$ & 0.01 \\
\hline eTextbook is worth the price & 5.17 & $\mathbf{4 . 6 8}$ & -0.49 \\
\hline eTextbook is fun to use & 3.74 & $\mathbf{3 . 9 9}$ & 0.25 \\
\hline eTextbook is visually appealing & 4.41 & $\mathbf{4 . 6 8}$ & 0.27 \\
\hline eTextbook content is current & 5.51 & 5.55 & 0.04 \\
\hline eTextbook content is of high quality & 5.39 & 5.49 & 0.10 \\
\hline $\begin{array}{l}\text { It is easy to access links from eText- } \\
\text { books }\end{array}$ & 5.35 & 5.30 & -0.05 \\
\hline Average & & & $\mathbf{0 . 0 1}$ \\
\hline
\end{tabular}

The relatively low scores for the two items "eTextbook is fun to use" and "eTextbook is visually appealing" are indicative of the current stage in the development of e-textbooks that lacks significant interactivity and multimedia features that e-books are capable of. Like most current etextbooks, the e-textbook used in this study is not substantially different from an electronic copy of the print book. However, the increasing sophistication of tools and their user interface, and the continued pressure on publishers to keep up with the technologies are likely to positively impact the visual appeal and interactivity of e-textbooks. The effect of differences in tools and methods used, such as reading an e-book as a webpage on laptops vs. reading it as a document on e-readers or high resolution large screens, on student perceptions is an area of further study.

The lower scores on "eTextbook is convenient to annotate" and "eTextbook is easy to read" are consistent with the comments made by many students that it (the e-book) isn't the same (as print book). There is a significant number of current college students who prefer the look and feel of paper books and the familiar way to flip through pages and annotate. Student comments also indicate some students, believed to be those who don't carry their laptops with them, consider it a disadvantage that they have to be online to read the book.

Items that scored low also include "eTextbook is worth the price." Electronic textbooks essentially are rented for a semester, and as such, cannot be kept for future reference or sold as second hand. Students apparently did not think that the difference in price between the electronic and print versions ( $\$ 19.95$ vs. 39.95 ) and other benefits like instant access anywhere anytime were sufficient to offset the negatives. Student rating of this item based on their perceived performance (4.68), was lower than what they expected (5.17).

All the above factors potentially contributed to the limited satisfaction with the e-textbook. Essentially the benefits didn't outweigh the drawbacks in students' views. These results are consistent with past studies, which showed that the majority of students preferred print books, indicating a lack of any recent significant improvements in e-textbooks.

\section{Determinants of Satisfaction}

Statistical analysis was done to identify the factors that contribute to satisfaction. Table 3 presents three different factors (indices) that were identified using factor analysis, and the correlation between each factor and the ten items. The expectation and performance indices are based on all ten 
significant items, and the disconfirmation index is based on seven items that have correlation coefficients greater than or equal to 0.5 . All three factors have high reliability scores represented by the Cronbach Alpha.

\begin{tabular}{|c|c|c|c|}
\hline \multicolumn{4}{|c|}{ Table 3: Correlation of items with indices } \\
\hline \multirow[b]{2}{*}{ Items } & \multicolumn{3}{|c|}{ Indices } \\
\hline & Expectation & Performance & Disconfirmation \\
\hline $\begin{array}{l}\text { eTextbook is convenient to access } \\
\text { (readily available) }\end{array}$ & 0.831 & 0.806 & 0.653 \\
\hline eTextbook is easy to access & 0.877 & 0.846 & 0.725 \\
\hline eTextbook is easy to read & 0.668 & 0.795 & 0.733 \\
\hline eTextbook is convenient to annotate & 0.517 & 0.736 & 0.660 \\
\hline eTextbook is worth the price & $<0.5$ & 0.688 & 0.675 \\
\hline eTextbook is fun to use & $<0.5$ & 0.701 & 0.632 \\
\hline eTextbook is visually appealing & $<0.5$ & 0.851 & 0.733 \\
\hline eTextbook content is current & 0.712 & 0.734 & 0.629 \\
\hline eTextbook content is of high quality & 0.756 & 0.825 & 0.737 \\
\hline It is easy to access links from eTextbooks & 0.770 & 0.796 & 0.672 \\
\hline Cronbach's Alpha & 0.926 & 0.935 & 0.897 \\
\hline
\end{tabular}

First, we test Hypotheses 2, $3 \& 4$ on the relationship between satisfaction and the three constructs:

Hypothesis 2: Satisfaction has a positive relationship with expectations.

Hypothesis 3: Satisfaction has a positive relationship with perceived performance.

Hypothesis 4: Satisfaction has a positive relationship with disconfirmation

To test these hypotheses, three separate simple regression analyses were conducted, keeping satisfaction as the dependent variable and varying the independent variable. That is, in each regression, satisfaction is a function of only one of the three indices. The main purpose of this analysis is to determine the magnitude and sign of the beta coefficient and find the explanatory power of each model.

Table 4 contains the standardized regression coefficients of the three models and other summary statistics along with the results of multiple regression analysis with performance and disconfirmation as independent variables.

The results show that each of the three factors has a beta coefficient that is significant at the 0.01 level, indicating a positive relationship with satisfaction. Thus, the results support all three hypotheses. However, expectation and disconfirmation explains only $11.2 \%$ and $9.5 \%$, respectively, of the 
variation in satisfaction as indicated by the adjusted $\mathrm{R}$ square values, whereas performance explains $61 \%$ of the variation.

Table 4: Results of regression analysis

\begin{tabular}{|c|c|c|c|c|c|}
\hline $\begin{array}{c}\text { Regression } \\
\text { Type }\end{array}$ & $\begin{array}{c}\text { Dependent } \\
\text { Variable }\end{array}$ & $\begin{array}{l}\text { Independent } \\
\text { Variable(s) }\end{array}$ & $\begin{array}{l}\text { Adjusted } \\
\text { R Square }\end{array}$ & $\begin{array}{l}\text { Standardized } \\
\text { Beta Coeffts }\end{array}$ & $\begin{array}{c}\text { Significance } \\
\text { Level }\end{array}$ \\
\hline Simple & Satisfaction & Expectation & 0.112 & 0.343 & 0.001 \\
\hline Simple & Satisfaction & Performance & 0.610 & 0.782 & 0.000 \\
\hline Simple & Satisfaction & Disconfirmation & 0.095 & 0.318 & 0.000 \\
\hline \multirow{2}{*}{ Multiple } & \multirow{2}{*}{ Satisfaction } & Performance & \multirow{2}{*}{0.615} & 0.810 & 0.000 \\
\hline & & Disconfirmation & & -0.059 & 0.307 \\
\hline
\end{tabular}

Table 4 also presents the results of the multiple regression analysis with performance and disconfirmation as independent variables. The adjusted $\mathrm{R}$ square of 0.615 for multiple regression, compared to 0.61 for the simple regression with performance alone as the independent variable, indicates that adding disconfirmation contributes very little in explaining the variation in satisfaction. Thus perceived performance is the predominant determinant of satisfaction. That is, the results do not support the disconfirmation theory that postulates that disconfirmation (perceived performance minus satisfaction) is the key determinant as found in the purchase of non-durable goods (Churchill \& Surprenant, 1982). The results of the current study on e-textbooks is consistent with the study by Moon, Philip \& Moon (2011) on e-tailing, which found perceived performance to be the key determinant of satisfaction.

\section{Intention to Use e-textbook in the Future}

Table 5 presents the distribution of student responses on their intention to use e-textbook in the future given the choice of electronic or print versions. Only $54 \%$ of students indicated that there is a moderately high or better probability that they will choose e-textbook in the future. A third of students gave a moderately low or worse chance that they will use e-textbook. However, this is an improvement over the results reported by Shepperd et al. (2008) with only one third of the etextbook users indicating that that they would use it again if given a chance.

\begin{tabular}{|l|r|}
\hline \multicolumn{2}{|c|}{ Table 5: Intention to use e-textbook } \\
\hline Intention to use e-textbook & Number of Students (\%) \\
\hline Certain or Almost Certain to Not Use (1) & $19(8 \%)$ \\
\hline Very Low Probability (2) & $35(15 \%$ \\
\hline Moderately Low Probability (3) & $27(11 \%)$ \\
\hline Neither High nor Low Probability (4) & $28(12 \%)$ \\
\hline Moderately High Probability (5) & $58(24 \%)$ \\
\hline Very High Probability (6) & $46(19 \%)$ \\
\hline Certain or Almost Certain to use (7) & $27(11 \%)$ \\
\hline Total & $240(100 \%)$ \\
\hline
\end{tabular}


Next, we test Hypothesis 5: There is no difference between e-textbook users and print book users in their intention to use e-textbooks.

Table 6 presents the mean scores obtained by using a 7-point scale (1 - Certain or Almost Certain not to use; 7 - Certain or Almost Certain to use).

\begin{tabular}{|l|r|r|r|r|}
\hline \multicolumn{7}{|c|}{ Table 6: Intention to use e-textbook in the future } \\
& \multicolumn{1}{|c|}{ Mean } & $\begin{array}{c}\text { Sample Size } \\
\text { (n) }\end{array}$ & \multicolumn{1}{|c|}{ Variance } & \multicolumn{2}{c|}{ t-Value } \\
\hline E-Text book & 4.55 & 156 & 3.31 & \multirow{2}{*}{$\mathrm{t}(.01,240)=2.60$} \\
\hline Print book & 3.87 & 84 & 3.30 & \\
\hline
\end{tabular}

As indicated by the significant $t$ value, those who use e-textbook are significantly more likely to choose e-textbooks in the future than those who use print books. There is no evidence that there will be any major shift to either version of the textbook from the other.

\section{Discussion}

This study found that the level of satisfaction of e-textbook users is almost the same as that of print book users. This seems to indicate that the benefits currently offered by the electronic version are not significant enough to offset the drawbacks. However, there is a slight improvement over results of past studies in which students showed a preference for print books. The advancements, however, seem to be gradual.

Analysis of the relationship between satisfaction and the three constructs (expectation, performance and disconfirmation) indicates that performance is the key determinant of satisfaction. Expectation prior to using e-textbook has minimal impact on satisfaction. The implication is that managing expectations to improve satisfaction is not a key concern in the case of e-textbooks. Unlike this study, results of consumer satisfaction studies with purchase of non-durable goods that are considered to be low-involvement decisions, have shown disconfirmation (perceived performance minus expectation) to be the key determinant of satisfaction. Whether or not the level of involvement of students in choosing between electronic and print versions has any impact on the determinants of satisfaction is an area of future research.

The study also found that, on the average, the probability that e-textbook users will choose etextbook in the future is less than moderately high. Similarly, there is only a low probability that print book users will switch to the electronic version. Again, this indicates the need for significant improvements in the cost and features of e-textbooks for them to be widely adopted.

\section{Limitations and Areas of Future Research}

Caution should be exercised in generalizing results of studies done on individual courses. The results of the current study that was done in an introductory information systems course may not be applicable to an upper level programming course where there is less need for sustained reading for which electronic media may be less suitable (Thomas, 2007). Similarly, the differences between students from different universities in their experience in using technology may impact their attitude towards e-textbooks. Areas of future study include addressing several other questions that are not covered in this paper: 
Investigation of Student Expectation, Perceived Performance and Satisfaction of E-textbooks

Is there a difference in attitudes toward e-books between students using different technologies, such as reading an e-book as a webpage on laptops vs. reading it as a document on e-readers? Is there a difference based on prior background in using e-books and e-readers?

How does e-textbooks compare with print books in terms of student learning, and what features of etextbooks, if any, would enhance student learning? A related question is, how does the characteristics of the course impact student attitude towards e-textbooks?

\section{Conclusion}

E-textbooks have the potential to be an appealing and effective low-cost option. However, these benefits are not fully realized in the e-textbook that was used in the study and in e-textbooks, in general. Student reactions to e-textbook are mixed potentially due to the lack of significant benefits to outweigh the drawbacks particularly due to lack of naturalness in e-textbooks. Students, in general, don't show any strong preference for e-textbook or print book.

It is conceivable that a student who preferred the e-textbook over the print book used in this study might prefer the print book in another subject area. Even for the same course, a student might prefer e-textbook for searching and brief lookups, but prefer print book for longer sessions of reading. Thus, the textbook adoption doesn't have to be an either or decision. Students might benefit from having both versions, which is feasible since many publishers offer the electronic version free with the print book. In adoption decisions, instructors should not solely depend on studies done on any individual course; but should consider the nature of the topics and the quality of the particular e-book that is considered.

The study shows that perceived performance is the predominant determinant of student satisfaction with e-textbooks, and that student expectations and disconfirmation (perceived performance minus satisfaction) have very little impact on satisfaction. That is, the results do not support the disconfirmation theory that postulates that disconfirmation (perceived performance minus satisfaction) is the key determinant as found in the purchase of non-durable goods. This result implies that managing student expectations to impact their satisfaction doesn't have to be a significant concern for instructors and publishers.

In summary, further improvement in cost as well as features that make e-textbooks more natural, appealing and effective is necessary for large scale adoption in higher education.

\section{References}

Apple. (2013). Retrieved November 11, 2013, from http://www.apple.com/ibooks-author/

Baker-Eveleth, L., Miller, J., \& Tucker, L. (2011). Lowering business education cost with a custom professor-written online text. Journal of Education for Business, 86(4), 242-252.

Berg, S., Hoffmann, K., \& Dawson, D. (2010). Not on the same page: Undergraduates' information retrieval in electronic and print books. The Journal of Academic Librarianship, 36(6), 518-525.

Buzzetto-More, N., Sweat-Guy, R., \& Elobaid, M. (2007). Reading in a digital age: E-books are students ready for this learning object? Interdisciplinary Journal of Knowledge and Learning Objects, 3, 239. 250. Retrieved July 6, 2013, from http://www.ijello.org/Volume3/IJKLOv3p239-250Buzzetto.pdf

Churchill, G., \& Surprenant, C. (1982). An investigation into the determinants of customer satisfaction. Journal of Marketing Research, 19, 491-504.

College Open Textbooks. (2013). Retrieved July 8, 2013, from http://www.collegeopentextbooks.org/

CourseSmart. (2013). Retrieved July 8, 2013, from http://www.coursesmart.com

Daniel, D., \& Woody, W. (2013). E-textbooks at what cost? Performance and use of electronic v. print texts. Computer \& Education, 62, 18-23. 
Diaz, A. (2012). Are free e-textbooks the future---or new fashioned copyright infringement? Retrieved July 7, 2013, from http://www.forbes.com/sites/janetnovack/2012/06/05/are-free-e-text-books-the-futureor-new-fashioned-copyright-infringement/

Engel, J., \& Blackwell, R. (1982). Consumer behavior. New York, NY: Dryden Press.

Falc, E. (2013). An assessment of college students' attitudes towards using an online e-textbook. Interdisciplinary Journal of E-Learning and Learning Objects, 9, 1-12. Retrieved from http://www.ijello.org/Volume9/IJELLOv9p001-012Falc831.pdf

Flatworldknowledge. (2013). Retrieved July 10, 2013, from http://catalog.flatworldknowledge.com/

Hoffelder, N. (2013). AAP: Ebook sales up 41\% in 2012 as growth slows down. Retrieved July 6, 2013, from http://www.the-digital-reader.com/2013/04/11/aap-ebook-sales-up-41-in-2012-as-growth-slowsdown/

Galy, E., Downey, D., \& Johnson, J (2011). The effect of using e-learning tools in online and campusbased classrooms on student performance. Journal of Information Technology Education: Research, 10, 209-230. Retrieved from http://www.jite.org/documents/Vol10/JITEv10p209-230Galy975.pdf

Kingkade, T. (2013).College textbook prices increasing faster than tuition and inflation. Retrieved from http://www.huffingtonpost.com/2013/01/04/college-textbook-prices-increase_n_2409153.html

Kolowich, S. (2010). All in the delivery. Insider Higher Education. Retrieved July 12, 2013, from http://www.insidehighered.com/news/2010/08/31/ebooks

Li, C., Poe, F., Potter, M., Quigley, B., \& Wilson, J. (2011). UC libraries academic e-book usage survey. University of California, Springer e-Book Pilot Project, Reader Assessment Subcommittee. Retrieved July 8, 2013 from http://www.cdlib.org/services/uxdesign/docs/2011/academic ebook usage survey.pdf

Lyman, F. (2008). Students enjoy lower costs, lighter backpacks as e-textbook availability expands dramatically. Community College Week, 8.

McFall, R. (2005). Electronic textbooks that transform how textbooks are used. The Electronic Library, 23(1), 72-81. doi: 10.1108/02640470510582754

Moon, S., Philip, G., \& Moon, S. (2011). The effect of involvement on e_satisfaction models. Service Marketing Quarterly, 32(4), 332-342.

Murray, M., \& Pérez, J. (2011). E-textbooks are coming: Are we ready? Issues in Informing Science and Information Technology, 8, 49-60. Retrieved July 14, 2013, from http://iisit.org/Vol8/IISITv8p049060Murray307.pdf

Murray, M., \& Pérez, J., Geist, D. \& Hedrick, A. (2012). Student Interaction with Online Course Content: Build It and They Might Come. Journal of Information Technology Education: Research, 11, 125-140. Retrieved from http://www.jite.org/documents/Vol11/JITEv11p125-140Murray1095.pdf

O'Hara, K., \& Sellen, A. (1997). A comparison of reading paper and on-line documents. Proceedings of the SIGCHI Conference on Human Factors in Computing Systems, ACM Press, 335-342. doi:10.1145/258549.258787

Oliver, R. (1993). Cognitive, affective, and attribute bases of the satisfaction responses. Journal of Consumer Research, 20, 418-507.

Oliver, R. (1997). Satisfaction: A behavioral perspective on the consumer. New York, NY: McGraw-Hill.

Owen, L. (2013). Bezos: With ebook sales up 70\% in 2012, Amazon has hit "transition" it expected. Retrieved July 1, 2013, from http://gigaom.com/2013/01/29/amazon-reports-increased-profits-andebook-sales-up-70-in-2012/

Parasuraman, A., Zeithaml, V. A., \& Berry, L. L. (1988). SERVQUAL: A multiple item scale for measuring consumer perceptions of service quality. Journal of Retailing, 64 (Spring), 12-37.

Price, G. (2013). Higher education: new white paper from Springer examines ebook adoption and usage at undergraduate universities. Retrieved July 9, 2013 
Investigation of Student Expectation, Perceived Performance and Satisfaction of E-textbooks

fromhttp://www.infodocket.com/2013/03/18/higher-education-new-white-paper-from-springerexamines-ebook-adoption-and-usage-at-undergraduate-universities/

Rockinson-Szapkiw, A., Courduff, J., Carter, K., \& Bennet, D. (2013). Electronic versus traditional print textbooks: A comparison study on the influence of university students' learning. Computers \& Education, 63, 259-266.

Sellen, A., \& Harper, R. (2002). The myth of the paperless office. Cambridge, MA: Massachusetts Institute of Technology Press.

Shepperd, J., Grace, J., \& Koch, E. (2008). Evaluating the electronic textbook: Is it time to dispense with text? Teaching of Psychology, 35, 2-5. doi: 10.1080/00986280701818532

Stone, R., \& Baker-Eveleth, L. (2013). Factors influencing students' likelihood to purchase electronic textbooks. Interdisciplinary Journal of E-Learning and Learning Objects, 9, 89-103. Retrieved from http://www.ijello.org/Volume9/IJELLOv9p089-103Stone0815.pdf

Thayer, A., Lee, C., Hwang, L., Sales, H., Sen, P., \& Dalal, N. (2011). The imposition and superimposition of digital reading technology: The academic potential of e-readers. Proceedings of the SIGCHI Conference on Human Factors in Computing Systems, ACM Press, 2917-2926. doi: $10.1145 / 1978942.1979375$

Thomas, S. (2007). Another side of the e-book puzzle. Indiana Libraries, 26(1), 39-45.

Wong, L. (2013). Student engagement with online resources and its impact on learning outcomes. Journal of Information Technology Education: Innovations in Practice, 12, 129-146. Retrieved from http://www.jite.org/documents/Vol12/JITEv12IIPp129-146Wong\%20FT116.pdf

Woody, W., Daniel, D., \& Baker, C. (2010). E-books or textbooks: Students prefer textbooks. Computers \& Education, 55, 945-948. doi: 10.1016/j.compedu.2010.04.005

Yi, Y. (1990). A critical review of consumer satisfaction. In V. A. Zeithaml (Ed.), Review of marketing (pp. 68-123). Chicago, IL: American Marketing Association.

Young, J. (2009). 6 lessons one campus learned about e-textbooks. The Chronicle of Higher Education, 55(39), A18.

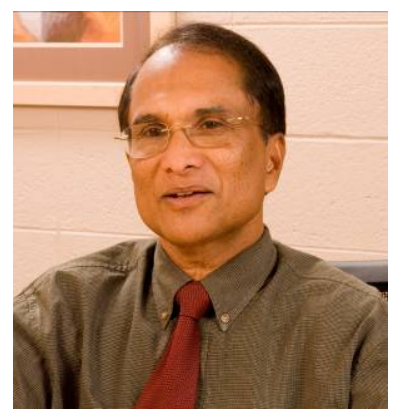

\section{Biographies}

George C. Philip, Ph.D. is a Distinguished Professor of Information Systems in the College of Business at the University of Wisconsin Oshkosh. His work experience includes Director of M.S. in Information Systems, chairperson of MIS program, and Senior Consultant with the Koehn Institute for Information Systems. His areas of publication, teaching and consulting include Business Intelligence, software design and development, database design, e-learning and e-collaboration.

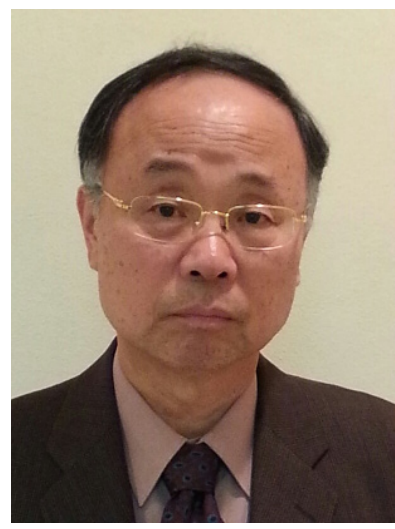

Soo-Young Moon, Ph.D. is an Associate Professor of Marketing in the College of Business at the University of Wisconsin Oshkosh. He has taught various marketing courses including international marketing, retail management, and marketing channels. He has made numerous presentations and publications in the areas of consumer satisfaction in e-tailing, the future of retailers, global retail strategy and others. 